\title{
Biogeochemistry and ecosystems of continental margins in the western North Pacific Ocean and their interactions and responses to external forcing - an overview and synthesis
}

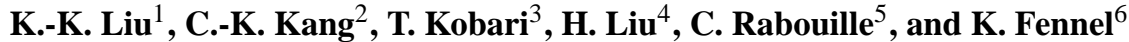 \\ ${ }^{1}$ National Central University, Chungli, Taiwan \\ ${ }^{2}$ Gwangju Institute of Science \& Technology, Gwangju, South Korea \\ ${ }^{3}$ Kagoshima University, Kagoshima, Japan \\ ${ }^{4}$ Hong Kong University of Science \& Technology, Hong Kong SAR \\ ${ }^{5}$ Laboratoire des Sciences du Climat et de l'Environnement, Gif-sur-Yvette, France \\ ${ }^{6}$ Dalhousie University, Halifax, Canada
}

Correspondence to: K.-K. Liu (kkliu@ncu.edu.tw)

Received: 12 June 2014 - Published in Biogeosciences Discuss.: 24 July 2014

Revised: 10 November 2014 - Accepted: 10 November 2014 - Published: 12 December 2014

\begin{abstract}
In this special issue we examine the biogeochemical conditions and marine ecosystems in the major marginal seas of the western North Pacific Ocean, namely, the East China Sea, the Japan/East Sea to its north and the South China Sea to its south. They are all subject to strong climate forcing as well as anthropogenic impacts. On the one hand, continental margins in this region are bordered by the world's most densely populated coastal communities and receive tremendous amount of land-derived materials. On the other hand, the Kuroshio, the strong western boundary current of the North Pacific Ocean, which is modulated by climate oscillation, exerts strong influences over all three marginal seas. Because these continental margins sustain arguably some of the most productive marine ecosystems in the world, changes in these stressed ecosystems may threaten the livelihood of a large population of humans. This special issue reports the latest observations of the biogeochemical conditions and ecosystem functions in the three marginal seas. The studies exemplify the many faceted ecosystem functions and biogeochemical expressions, but they reveal only a few longterm trends mainly due to lack of sufficiently long records of well-designed observations. It is critical to develop and sustain time series observations in order to detect biogeochemical changes and ecosystem responses in continental margins and to attribute the causes for better management of the environment and resources in these marginal seas.
\end{abstract}

\section{Introduction}

Continental margins in the western North Pacific Ocean are distinguished by the strong western boundary current, namely, the Kuroshio, and its intense interactions with the three marginal seas, namely, the South China Sea (SCS), East China Sea (ECS) and Japan/East Sea (JES, also EJS). Among the three, the SCS and ECS receive voluminous runoffs from some of the largest rivers in the world, while the SCS and JES have very deep basins making them like miniature oceans. The complicated environmental settings provide the three marginal seas with highly diverse habitats, which nurture some of the most productive large marine ecosystems in the world and sustain very active biogeochemical processes. The total fish catch exceeded 15 million tons in recent years (Anon, 2011; NOAA, 2013, 2011).

Biogeochemistry and ecosystems in the three marginal seas are sensitive to atmospheric forcing and land-to-ocean fluxes (e.g., Tseng et al., 2011; Gong et al., 2011; Kim et al., 2011). While the JES and SCS behave as miniature oceans responsive to climate forcing, the East China Sea serves as the quintessential example of effective $\mathrm{CO}_{2}$ drawdown in a continental shelf setting, based on which the term "continental shelf pump" was first coined (Tsunogai et al., 1999). It later inspired important findings about the marine carbon cycle (e.g., Thomas et al., 2004). Recent studies demonstrate how the $\mathrm{CO}_{2}$ uptake capacity in the ECS is controlled by 


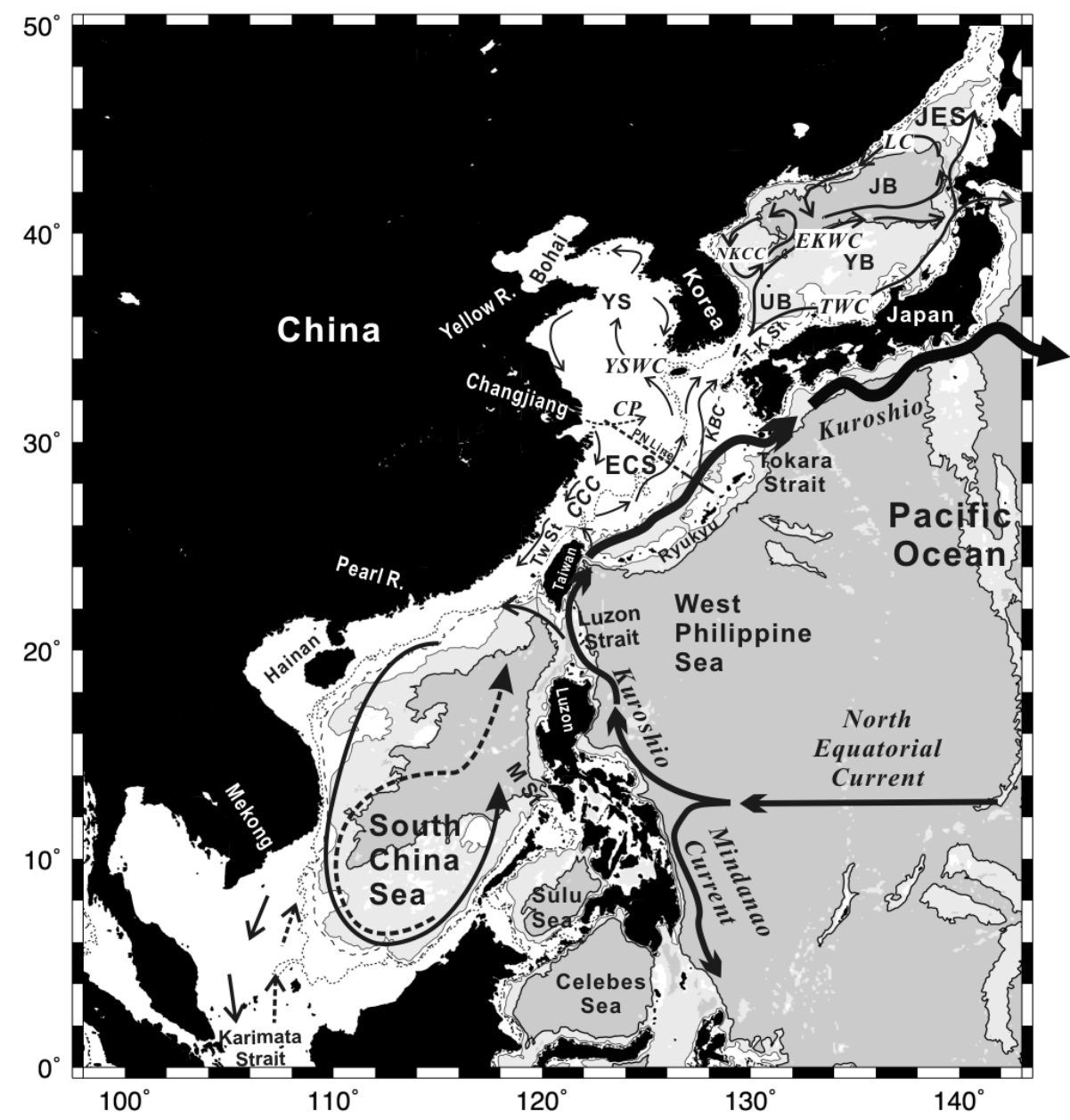

Figure 1. Marginal seas in the western North Pacific Ocean. The contours are isobaths of $100 \mathrm{~m}$ (dotted), $200 \mathrm{~m}$ (dashed), $1000 \mathrm{~m}$ (thin solid) and $3000 \mathrm{~m}$ (thick solid). Sea floor deeper than $3000 \mathrm{~m}$ is shaded in grey. The Kuroshio is the strong western boundary current that flows through this region and interacts extensively with the three major marginal seas, namely, the South China Sea (SCS), East China Sea (ECS) and the Japan/East Sea. The ECS connects with the Yellow Sea, which in turn connects to the Bohai Sea, forming one of the largest contiguous continental shelves in the world. Four large rivers empty into the continental margins. The Mekong and the Pearl River discharge into the SCS; the Changjiang river discharges into the ECS, forming a distinct large river plume (Changjiang plume, CP) in summer; the Yellow River discharges into the Bohai Sea. The circulations within the marginal seas change seasonally. The stronger winter monsoon usually drives stronger currents, which are shown in solid curves. However, the weaker summer monsoon does cause some changes in currents; the more notable ones are shown as dashed curves. See Table 1 for abbreviations.

fluctuation of the Changjiang (i.e., Yangtze River) discharge (Tseng et al., 2011; C.-M. Tseng et al., 2014), which is in turn influenced by climate oscillation. The densely populated coastal zones in this region exert intense stresses that may alter the biogeochemical cycles and threaten the wellbeing of marine ecosystems (e.g., Cai et al., 2011). One critical case is the anthropogenic nutrient-induced hypoxia in the ECS (Liu et al., 2015) with observed areas exceeding $15000 \mathrm{~km}^{2}$ in some years (Zhu et al., 2011), which is as severe as the dead zones in the Mississippi outflow region in terms of hypoxic area (Fennel et al., 2013). Moreover, the altered biogeochemical cycles may cause unknown feedbacks that could exacerbate the effects of climate change.
This special issue on "Biogeochemistry and ecosystems in the western north Pacific continental margins under climate change and anthropogenic forcing" (Liu et al., 2014) reports on the biogeochemistry and ecosystems, how they interact with each other and how they respond to climate drivers and multiple anthropogenic stressors in the three marginal seas. Such understanding will better prepare our societies in facing the potentially adverse effects occurring in the changing continental margins. We first describe the environmental settings of the three marginal seas and then highlight notable findings in five topical areas:

1. increasing atmospheric $\mathrm{CO}_{2}$ and changing carbonate chemistry 
2. regional biogeochemical processes

3. continental margin biota and their ecological characteristics

4. physical forcing and nutrient transport

5. phytoplankton responses to external forcing

\section{Environmental settings}

All three marginal seas are significantly affected by the Kuroshio, which is the strong western boundary current in the North Pacific Ocean originating from a bifurcation of the North Equatorial Current to the east of the Luzon Island (Fig. 1). It flows northward off the eastern coast of Luzon and Taiwan, and along the shelf edge of the East China Sea and then turns eastward southwest of Kyushu. Along the way the Kuroshio or its branches intrude into all three marginal seas, first the SCS, then the ECS, and finally the JES, bringing strong influences on the hydrographic and biogeochemical properties. The two-way exchanges with the South and East China seas also result in significant modification of the Kuroshio water properties (Liu et al., 2010a, b).

The SCS, which spans from 1.5 to $23^{\circ} \mathrm{N}$, is located in tropical southeast Asia (Fig. 1). It has a total area of 3.35 million $\mathrm{km}^{2} ; 40.5 \%$ of it is the shelf, defined as regions with bottom depths less than $100 \mathrm{~m}$, and the rest is the interior, where the depth attains a maximum of $5006 \mathrm{~m}$ (Liu et al., 2010b). The surrounding land masses and islands make the SCS a semi-enclosed water body. It is connected to the West Philippine Sea (WPS) through the Luzon Strait between Taiwan and Luzon, which has an effective sill depth around $2000 \mathrm{~m}$ and serves as the only channel for the exchange of deep water with the ocean outside. The SCS is connected with the Sulu Sea (Fig. 1) mainly through the Mindoro Strait (with sill depth at $420 \mathrm{~m}$ ). The Taiwan Strait to the north and the Karimata Strait to the south are rather shallow $(\mathrm{ca} .60 \mathrm{~m}$ ) and so allow only limited exchange of waters with the East China Sea to the north and the Java Sea to the south (Fig. 1). The many channels and passages between the SCS and its surroundings make the water exchange rather efficient, with an estimated residence time of about 50 years for the basin water (Liu et al., 2010b).

The ECS spans between China and the Ryukyu Islands with Taiwan as its southern bound and the Yellow Sea (YS) and Bohai Sea (BS) as its northern neighbor (Fig. 1). The ECS together with the YS and BS forms one of the largest contiguous continental shelves in the world. The total area of the shelf down to the isobath of $200 \mathrm{~m}$ is about $1 \mathrm{mil}-$ lion $\mathrm{km}^{2}$ with an average depth of $63 \mathrm{~m}$ (Liu et al., 2010a). Seaward from the continental shelf is the Okinawa Trough (just to the north of the Ryukyu Islands in Fig. 1), which extends from Kyushu to Taiwan with a maximum depth around $2000 \mathrm{~m}$. The ECS is connected to the JES through the
Tsushima/Korea Strait (T-K St.) to the northeast, and connected to the Pacific Ocean through the Tokara Strait and many gaps in the island chain to the east.

The JES (Fig. 1) is a semi-enclosed marginal sea with only four narrow and shallow $(<150 \mathrm{~m})$ straits connected to outer seas whereby its water exchange is fairly restricted (Kang et al., 2010). However, it is a rather deep marginal sea, with an average depth of about $1700 \mathrm{~m}$ and exceeding $3700 \mathrm{~m}$ in deeper places. Thus, the interior of the JES is virtually isolated from the Pacific and this imposes unique characteristics which will be introduced further below. The JES covers an area about 1.0 million $\mathrm{km}^{2}$. Its topographic features are summarized as consisting of three basins: the Japan Basin, the Ulleung Basin, and the Yamato Basin.

\subsection{External forcings}

All three marginal seas experience the southerly monsoon from May to August and the northerly monsoon from October to March of the next year. The winter monsoon is usually stronger than the summer monsoon. These seas are frequently subject to typhoons, with the SCS seeing the highest number. From 1950 to 2001 there were on average 10 typhoons entering the SCS every year (http://www.usno.navy. mil/JTWC/). Most typhoons occurred to the north of $10^{\circ} \mathrm{N}$ from May to October. Typhoons usually bring a considerable amount of rain to the region.

Both the SCS and the ECS shelf receive large riverine discharges of water and suspended sediments (Liu et al., 2010a). The Changjiang, which has an estimated average discharge of $928 \mathrm{~km}^{3} \mathrm{yr}^{-1}$ to the ECS, is by far the largest source of riverine discharge. Second to Changjiang, the Mekong River and the Pearl River discharge 470 and $300 \mathrm{~km}^{3} \mathrm{yr}^{-1}$, respectively, to the SCS. The ECS and the SCS receive about the same amount of total runoff of $1300 \mathrm{~km}^{3} \mathrm{yr}^{-1}$, which carries huge amounts of suspended sediments and nutrient loads in both cases (Liu et al., 2010a, b).

Aside from river discharges, all three marginal seas receive sizable contributions of macro- and micro-nutrients via dry and wet depositions from the atmosphere (e.g., Kim et al., 2011; Wang et al., 2012). The sources of the Aeolian fluxes are dusts and aerosols from industrial or biomass burning sources (Hsu et al., 2009; Lin et al., 2007, 2009).

\subsection{Circulation and hydrography}

The Kuroshio (Fig. 1) to the east of the Luzon Island has an estimated transport of 14-16 Sv (Sverdrups) (Liu et al., 2010a). As the Kuroshio flows northward passing the Luzon Strait, its path makes a slight detour intruding into the SCS with only a small fraction (2-4 Sv) actually entering the interior, mostly during winter. Passing by the east coast of Taiwan, the Kuroshio enters the ECS with a mean transport of 21.5 Sv entering the ECS. As it encounters the shelf edge of the ECS, the Kuroshio turns northeastward following 
Table 1. List of abbreviations of geographic names and currents.

\begin{tabular}{llll}
\hline Abbr. & Geographic names & Abbr. & Current names \\
\hline BS & Bohai Sea & CCC & China Coastal Current \\
ECS & East China Sea & EKWC & Eastern Korean Warm Current \\
JB & Japan Basin & KBC & Kuroshio Branch Current \\
JES & Japan/East Sea & LC & Liman Current \\
M St & Mindoro Strait & NKCC & North Korean Cold Current \\
SCS & South China Sea & TWC & Tsushima Warm Current \\
T-K St & Tsushima/Korea Strait & YSWC & Yellow Sea Warm Current \\
Tw St & Taiwan Strait & & \\
UB & Ulleung Basin & & \\
YB & Yamato Basin & & \\
YS & Yellow Sea & & \\
\hline
\end{tabular}

the isobaths, and separates from the shelf and flows around the southern tip of Kyushu. The Kuroshio transport in the ECS (23.7 $\pm 2.0 \mathrm{~Sv}$, Ichikawa and Beardsley, 1993) is similar to that observed off Taiwan. Clearing the Tokara Strait, the Kuroshio enters the open Pacific Ocean becoming the Kuroshio Extension, which is characterized by extensive meandering and recirculation (Qiu, 2002).

The currents within the SCS are rather weak with changing directions in responses to the forcing of alternating monsoons (Fig. 1), which drive a cyclonic gyre in winter and a reversed circulation in summer (Shaw and Chao, 1994; Chen et al., 2012). Aside from the Kuroshio intrusion in the upper water column through the Luzon Strait, the deep and intermediate water inflows induce a basin wide upwelling (Chao et al., 1996). The net inflow is balanced by outflow through other channels, including the Taiwan Strait and the Mindoro Strait in the north and the Karimata Strait in the south. The southern outflow forms the so-called SCS throughflow, which interacts with the Indonesian throughflow (Gordon et al., 2012).

Passing by Taiwan, the Kuroshio branches off in several places along the ECS shelf break, most notably to the northeast of Taiwan and to the southwest of Kyushu. Off northeastern Taiwan, the intruding Kuroshio water forms a cyclonic eddy in the surface layer with the subsurface water onwelling along the slope and shelf bottom (Liu et al., 1992a, b) and some shelf water veering off the shelf. Therefore, this is a region of active exchange of water and geochemical materials between the shelf and the open ocean. An intruding Kuroshio Branch Current (KBC) combined with the northward flow from the Taiwan Strait forms the Taiwan Warm Current (Ichikawa and Beardsley, 2002). There is a persistent northward flow near the bottom through the Taiwan Strait from the SCS, while the surface flow is normally northward but changes direction when the northerly wind is strong and persistent in winter.

Southwest of Kyushu, a KBC intrudes onto the shelf to form the Tsushima Current, flowing towards the Tsushima/Korea Strait (Fig. 1). In summer, the Taiwan Warm Current also contributes to the Tsushima Current (Ichikawa and Beardsley, 2002). In winter (Fig. 1), the intruding Kuroshio Branch Current is the main source of the Tsushima

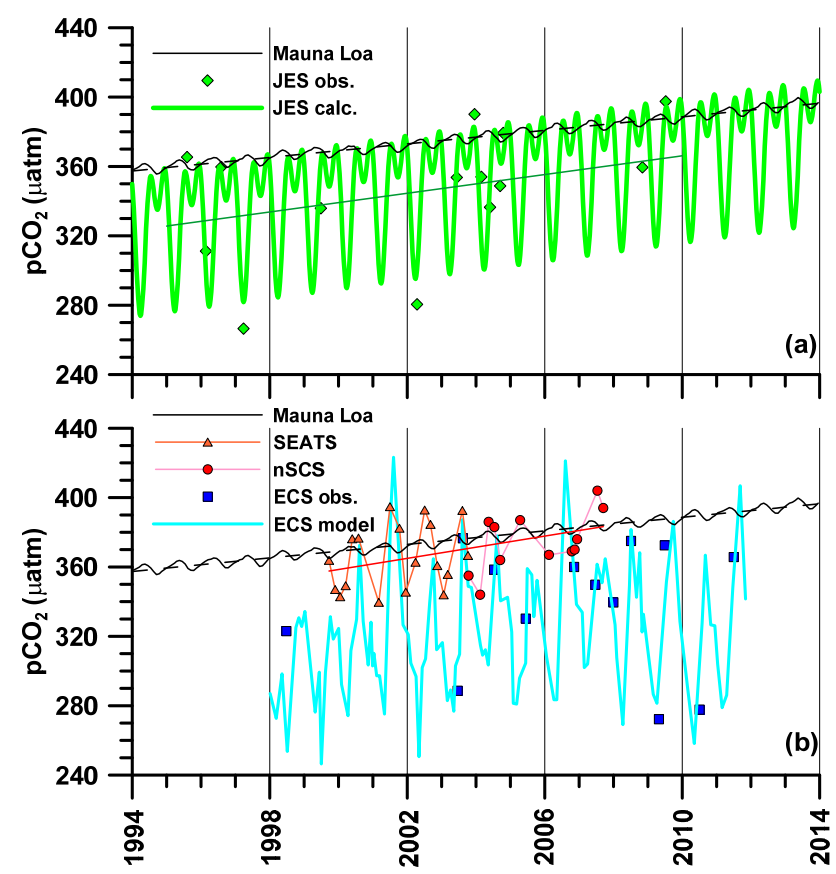

Figure 2. Observed partial pressure of $\mathrm{CO}_{2}$ in surface waters of the three marginal seas examined in this special issue, namely, (a) the Japan/East Sea (Kim et al., 2014), (b) the East China Sea (Tseng et al., 2011; C.-M. Tseng et al., 2014) and the South China Sea (Tseng et al., 2007; Zhai et al., 2013). Also plotted are the $p \mathrm{CO}_{2}$ in the air observed at Mauna Loa, Hawaii. Both the JES and the SCS show a clear trend of increasing $p \mathrm{CO}_{2}$, while the ECS does not show a clear trend due to strong variability and insufficient measurement (see text).

Current, and also feeds into the Yellow Sea Warm Current (YSWC, Lie et al., 2001).

Dispersal of the Changjiang discharge varies seasonally (Lee and Chao, 2003). Normally the Changjiang freshwater discharge should drive a southward coastal jet, but, forced by the southwest monsoon in summer, the plume becomes diffuse and disperses towards the east or northeast and may enter the JES. Under the northerly monsoon in winter (Fig. 1), the plume follows a narrow coastal jet, extending southward (Lee and Chao, 2003), which is often named the China Coastal Current (CCC).

There are four major currents in the JES (Senjyu, 1999), namely, the Tsushima Warm Current (TWC), the East Korean Warm Current (EKWC), the Liman Current (LC) and the North Korean Cold Current (NKCC) (Fig. 1). The Tsushima Warm Current is the only significant source of water inflow to the JES. Unlike the other two marginal seas, river discharges are not important to the JES. The saline Tsushima Warm Current flows over the colder and less saline waters of the homogeneous Proper Water and out to the Pacific through the Tsugaru and Soya Straits. The northflowing warm water forms a strong zonal polar front around 
Table 2. Trends of observed $p \mathrm{CO}_{2}$ in surface waters of the marginal seas. Also listed is that in the air from Mauna Loa for comparison.

\begin{tabular}{lllrrr}
\hline Site & Period & Trend $\left(\mu \mathrm{atm} \mathrm{yr}^{-1}\right)$ & $n$ & $R^{2}$ & $p$ \\
\hline JES & $1995-2009$ & $3.9 \pm 2.2(2.7 \pm 1.1)^{\mathrm{a}}$ & 14 & 0.227 & 0.085 \\
ECS & $1998-2011$ & - & 13 & - & - \\
SCS & $1999-2007$ & $3.2 \pm 1.4^{\mathrm{b}}$ & 30 & 0.177 & 0.021 \\
Mauna Loa & $1994-2013$ & 1.95 & 240 & 0.963 & $<0.001$ \\
\hline
\end{tabular}

a The trend is obtained by simple linear regression of the observed values; that in parenthesis is determined by more sophisticated trend fitting (Kim et al., 2014). ${ }^{\mathrm{b}}$ The trend is obtained by linear regression of the observed values from the SEATS station (Tseng et al., 2007) and from Domain B of the northern SCS (Zhai et al., 2013).

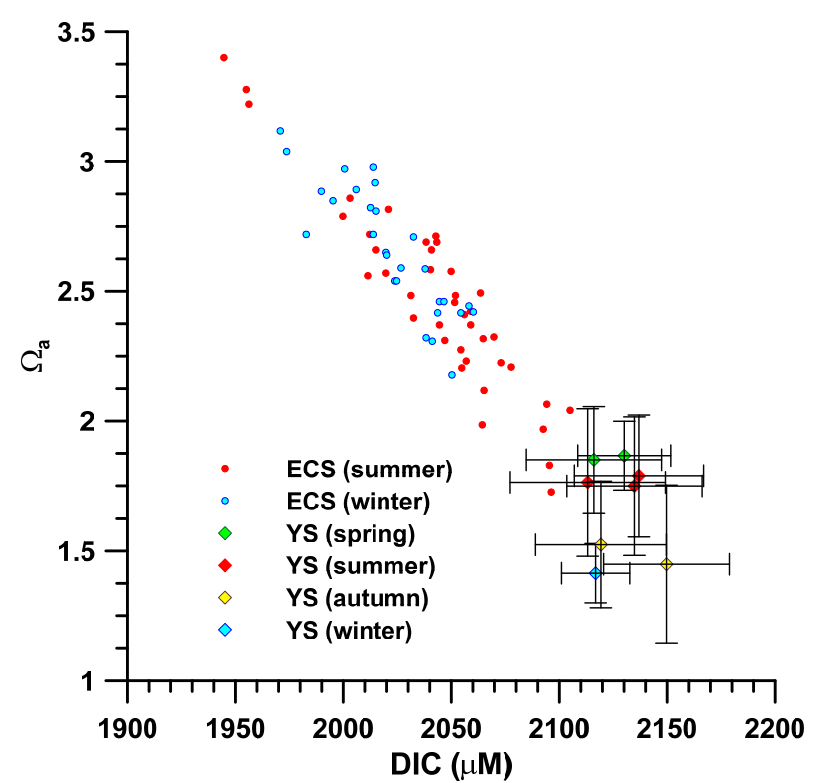

Figure 3. Aragonite saturation $\left(\Omega_{\mathrm{a}}\right)$ vs. DIC in the bottom waters of the ECS (Chou et al., 2013b) and the YS (Zhai et al., 2014). The data points of the YS are areal mean values from each cruise. The trend indicates the lowering of aragonite saturation in correspondence to increasing accumulation of DIC from respiration.

$40^{\circ} \mathrm{N}$ against the south-flowing North Korean Cold Current (Fig. 1).

Recent studies (e.g., Kang et al., 2010) clearly indicate that the JES has undergone a dramatic change in the last 50 years possibly due to climate forcing. The dissolved oxygen concentration in the deep Japan Basin has decreased significantly since the 1930s, and the oxygen minimum has been deepening successively since the late 1960s.

\section{Highlights of findings}

\subsection{Increasing atmospheric $\mathrm{CO}_{2}$ and changing carbonate chemistry}

The $\mathrm{CO}_{2}$ partial pressure in the surface water has been carefully studied in all of the marginal seas examined in this spe- cial issue. Kim et al. (2014) reported the repeat observations in the Ulleung Basin. Chou et al. (2013a) contrasted the different seasonal patterns of $p \mathrm{CO}_{2}$ in the ECS in the 1990s and the 2000s. Zhai et al. (2013) surveyed the entire SCS over 6 years to assess the air-sea $\mathrm{CO}_{2}$ exchange fluxes. They concluded that most of the SCS is a source of $\mathrm{CO}_{2}$ to the atmosphere while the Pearl River estuary zone is a slight sink, the overall SCS being a net source of $\mathrm{CO}_{2}$ to the atmosphere. We have compiled time series of $p \mathrm{CO}_{2}$ in surface water at a few representative sites of the three marginal seas (Fig. 2) and conducted regression analysis to determine the trends (Table 2).

Following the increasing $\mathrm{CO}_{2}$ partial pressure in the air, the JES and the SCS have shown a clear increasing trend of $p \mathrm{CO}_{2}$ in the surface water (Table 2), while the trend in the ECS is unclear due to the complex situation there, including the strong impact of the Changjiang discharge on the biogeochemical processes of the ECS. The observed $p \mathrm{CO}_{2}$ in the Ulleung Basin yield a rather large increasing trend with very large uncertainty due to the strong seasonal variation (Table 2). Using a sophisticated data processing technique to delineate the seasonal variation, Kim et al. (2014) obtained a moderately strong trend of $2.7 \pm 1.1 \mu \mathrm{atm}^{-1} \mathrm{r}^{-1}$. For the SCS, we have constructed a time series from observations from the South East Asia Time-Series Study (SEATS) station (Tseng et al., 2007) and observations from Domain B in the northern SCS, which covers the SEATS station (Zhai et al., 2013). The two data sets show good agreement for the observations in 2003. The composite time series shows a strong increasing trend of $3.2 \pm 1.4 \mu \mathrm{atm} \mathrm{yr}^{-1}$. Both trends are significantly stronger than the increasing trend of $p \mathrm{CO}_{2}$

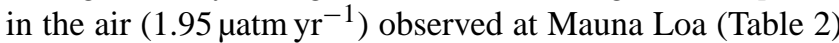
or that in the surface water $\left(1.82 \pm 0.07 \mu \mathrm{atm} \mathrm{yr}^{-1}\right)$ observed at the HOT (Hawaii Ocean Time-series) station in the central Pacific (Rhein et al., 2013). The faster increasing trends in the marginal seas probably induce the decreasing capacity of $\mathrm{CO}_{2}$ storage in the more confined water bodies of the marginal seas, which warrant further investigation.

Chou et al. (2013a) reported dramatic changes in the seasonal patterns of $p \mathrm{CO}_{2}$ variation in the East China Sea, reflecting the complicated controlling factors. In contrast to the general increasing trend of $p \mathrm{CO}_{2}$, the observed $p \mathrm{CO}_{2}$ 


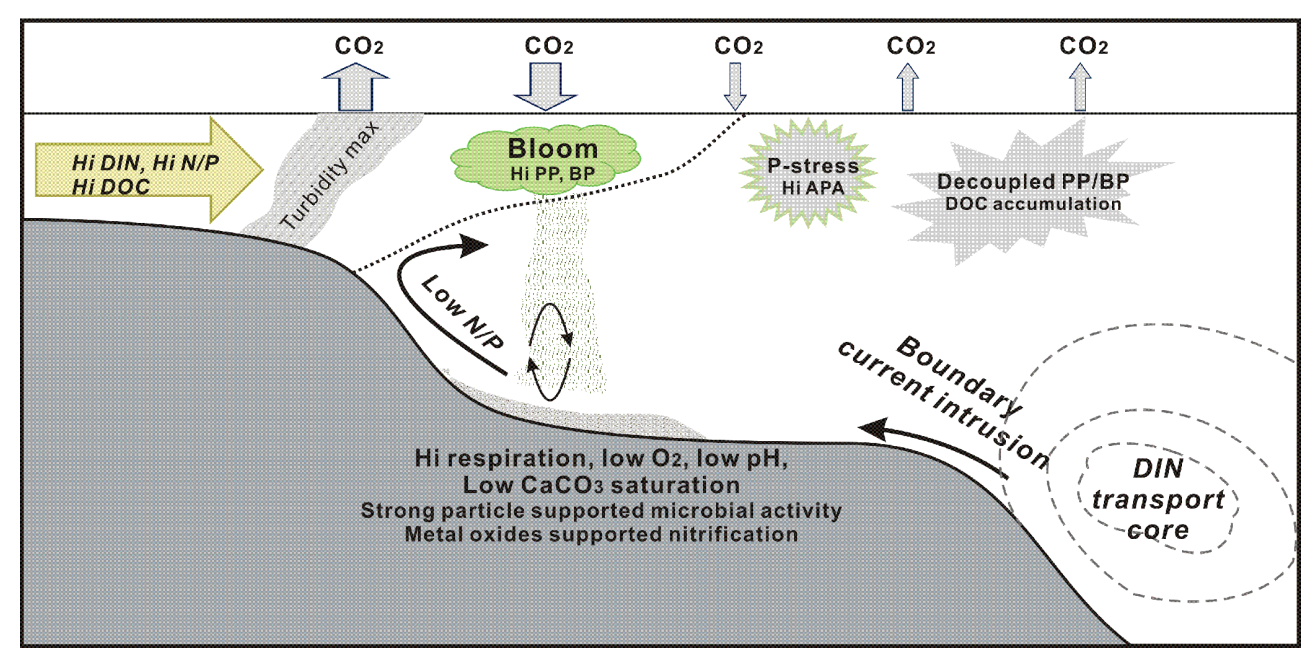

Figure 4. Schematic diagram showing the major biogeochemical features in the river-shelf-boundary current systems observed in studies of this special issue. Riverine nutrients-induced phytoplankton bloom in the river plume draws down $p \mathrm{CO}_{2}(\mathrm{Chen}$ et al., 2013) and produces high particulate organic carbon (POC) flux (Hung et al., 2013), which causes strong community respiration (Chen et al., 2013) probably driven by active resuspension (Hung et al., 2013). The elevated particle concentrations near the river mouth sustain exceptionally high microbial activities, which include nitrification processes facilitated probably by the particle-borne metal oxides (Hsiao et al., 2014). Consequently, low oxygen, low $\mathrm{pH}$ and low aragonite saturation occur in the bottom water beneath the surface algal bloom in the Changjiang river plume and also in the YS (Chou et a., 2013b; Zhai et al., 2014). Although the riverine nutrient loads in east Asia are often enriched in dissolved inorganic nitrogen (DIN) resulting in high $\mathrm{N} / \mathrm{P}$ ratio, P-limitation does not happen in the river plume because of the nutrient supply with low N / P from the marine origin provided by upwelling and entrainment associated with the river plume (Y. F. Tseng et al., 2014). Instead P-stress occurs in the outer rim of the river plume and often induces high alkaline phosphatase activities (AKA). The nutrient supply from marine origin is often actuated by intrusion onto the shelf from boundary currents, such as the Kuroshio, which carries a large nutrient load with a subsurface core (Guo et al., 2013). In the inner shelf where nutrients are replete, primary production (PP) and bacterial production (BP) are tightly coupled driving a rapid turnover of dissolved organic carbon (DOC), whereas, in the oligotrophic outer shelf, the two are decoupled and DOC tends to accumulate due to low turnover rate (Lai et al., 2014).

in the Changjiang plume in summer appeared to have shown a decrease, which is attributed to the enhanced $\mathrm{CO}_{2}$ uptake by phytoplankton due to the increasing load of riverine nutrients. Subsequent to the phytoplankton bloom, water column respiration led to the elevated $p \mathrm{CO}_{2}$ in the surface water in autumn. Contrary to the consistent trends of $p \mathrm{CO}_{2}$ increase in the JES and SCS, the monthly average $p \mathrm{CO}_{2}$ values of the whole ECS derived for the period of 1998 to 2012 (C.-M. Tseng et al., 2014) do not show a significant trend (Fig. 2). The aforementioned dramatic changes induced by the highly variable Changjiang discharge have probably masked the long-term $p \mathrm{CO}_{2}$ trend.

Aside from driving unusual changes in $p \mathrm{CO}_{2}$, the eutrophication-induced algal bloom in the Changjiang outflow region also spurred extreme conditions of carbonate saturation $(\Omega)$. Chou et al. (2013b) observed very high aragonite saturation $\left(\Omega_{\mathrm{a}}\right)$ values, up to 5.8 , in the surface water off of the mouth of the Changjiang in summer, but very low $\Omega_{\mathrm{a}}$ values (as low as 1.7) in the bottom water beneath the plume. Fig. 3 shows the wide range of $\Omega_{\mathrm{a}}$ values in the bottom water of the ECS (Chou et al., 2013b), which reveal a strong negative correlation with the concentration of dissolved inorganic carbon (DIC). Such a trend is consistent with the notion of exacerbation of acidification by eutrophication (Cai et al.,
2011). In winter the range of $\Omega_{\mathrm{a}}$ was considerably smaller with minimum value above 2 , apparently resulting from cooling and water column overturning.

An even lower degree of aragonite saturation (Fig. 3) has occurred in the bottom water of the YS (Zhai et al., 2014). The data points shown in Fig. 3 are the areal mean values, which show the lowest $\Omega_{\mathrm{a}}$ values around 1.4 observed in autumn and winter, while the lowest individual value (1.13) occurred in October 2011. Contrary to observations in the ECS, the YS showed the lowest values in autumn instead of summer. Zhai et al. (2014) attributed the lowest aragonite saturation to the cumulative effect of respiration in the bottom water of the YS. However, there are no reported values in autumn for the ECS so that we cannot rule out the possibility that the lowest value there may also occur in autumn. It is noteworthy that the acidification in the bottom waters of both areas are enhanced by high productivity, probably related to eutrophication. Although the total riverine supply of DIN to the Bohai-Yellow Sea is considerably less than that to the ECS according to the compilation of Liu et al. (2010a), the observed aragonite saturation values in the YS are lower than most observed in the ECS (Fig. 3). This probably reflects the difference in shelf water residence time of the two areas. For the combined Bohai-Yellow Sea, the water residence time 
is estimated to be 1.7 years (Lee et al., 2004), whereas the southern ECS, south of the mouth of the Changjiang, has an estimated residence time of about 0.5 years or less (Liu et al., 2010a). The longer residence time would enhance the accumulation of DIC from respiration, which may explain the lower $\Omega$ values in the YS.

\subsection{Regional biogeochemical processes}

Because estuaries and coastal regions are the most biogeochemically active zones, particularly in regions with rapid economic development and population growth (Jennerjahn, 2012), we have constructed a schematic diagram to illustrate the major biogeochemical features in the estuary-shelfboundary current system (Fig. 4). Many findings reported in this special issue are presented in this figure, which is modified and amended following the diagrams of Y. F. Tseng et al. (2014), Tseng et al. (2011), and Cai and Lohrenz (2010).

In the Changjiang estuary and its outflow region in the East China Sea, the two papers by Hung et al. (2013) and Hsiao et al. (2014) describe the fate and importance of the mix of terrigenous and marine particles in the continental shelf area. Hung et al. (2013) describes the particulate flux of organic carbon from the sea surface to the bottom as measured by sediment traps during summer. One major caveat of these measurements on continental shelves is sediment resuspension (Fig. 4), because it modifies the export flux and its chemical composition. Hung et al. (2013) uses a resuspension model, which is able to provide an estimate of the resuspended fraction collected in sediment traps. This fraction amounts from 27 to $93 \%$ of the total flux. Vertical POC fluxes range from $60 \mathrm{mg} \mathrm{C} \mathrm{m}^{-2} \mathrm{day}^{-1}$ in the outer shelf to $785 \mathrm{mg} \mathrm{C} \mathrm{m}^{-2}$ day $^{-1}$ in the inner shelf. The high POC fluxes in the inner shelf supports the notion mentioned earlier that a high respiration rate sustained by local supply of organics causes the low aragonite saturation in the bottom water. This is a first attempt to correct for the overestimation due to resuspension in sediment trap fluxes in the ECS and more tracer studies should be performed in order to better characterize resuspension and thus vertical fluxes.

Hsiao et al. (2014) concentrated on the Changjiang River plume and nitrification processes, which convert ammonium to nitrate. This process consumes oxygen in the reaction which may contribute to hypoxia in eutrophicated regions (e.g., Pearl River, Dai et al., 2006). Nitrification rates are correlated to ammonium concentration with a peak at a salinity of $29 \mathrm{psu}$ (practical salinity unit) and they are larger in bulk water than particle-free water. Furthermore, when compared to community respiration, a measure of total oxygen consumption in a sample of water, it is shown that a significant share of oxygen consumption is used by the nitrification process. In half of the cases, this share exceeds the Redfield ratio (23\%) and in three occasions exceeds $100 \%$ (up to $318 \%$ ). This is only possible if other oxidants can be used for nitrification (such as $\mathrm{Mn}$ or $\mathrm{Fe}$ oxides). These are abundant in the turbid plume of the Changjiang and deserve more attention in order to understand nitrogen cycling in turbid estuaries (Fig. 4).

On a smaller scale in the northwestern SCS, Li et al. (2014) studied the nutrient dynamics in a number of rivers and estuaries on the east coast of the Hainan Island. They found that all rivers are enriched in dissolved inorganic nitrogen relative to phosphate, due to high nitrate input. Based on a steady-state box model, riverine and groundwater inputs, with additional input from aquaculture effluents, were the major sources of nutrients to the east coast of the Hainan Island.

For the open SCS, Yang et al. (2014) estimated the fluxes of nitrate and ammonium in atmospheric deposition at a remote island (Dongsha) in the northern SCS and examined the potential sources of deposited nitrate from its dual isotopic composition $\left(\delta^{15} \mathrm{~N}_{\mathrm{NO}_{3}}\right.$ and $\left.\delta^{18} \mathrm{O}_{\mathrm{NO}_{3}}\right)$ in different seasons. It is interesting to evaluate possible impacts of atmospheric nitrogen deposition to nutrient budget in this region. Their measurements suggest that the majority of atmospheric deposition of reactive nitrogen was sourced from mainland China driven by the prevailing winter monsoon, whereas contributions from tropical cyclones and southeastern Asian biomass burning could be significant in summer. This is evidenced by the dual isotope ratios in atmospheric deposition. They estimate annual total atmospheric inorganic nitrogen deposition of $\sim 50 \mathrm{mmol} \mathrm{N} \mathrm{m}^{-2} \mathrm{yr}^{-1}$, stimulating a new production of $\sim 330 \mathrm{mmol} \mathrm{C} \mathrm{m}^{-2} \mathrm{yr}^{-1}$. Then they propose that this potential $\mathrm{CO}_{2}$ uptake would mitigate $\sim 50 \%$ of the $\mathrm{CO}_{2}$ release from the northern SCS. Although considerable uncertainties arose due to the lack of separation between the flux-weighted average $\delta^{15} \mathrm{~N}$ of nitrate and the isotopic signal from $\mathrm{N}_{2}$ fixation, this finding demonstrates that atmospheric deposition may serve as an important external supplier of reactive nitrogen to the SCS.

\subsection{Continental margin biota and their ecological characteristics}

The two major pathways for energy and material flows in lower trophic levels of pelagic ecosystems are the grazing food chain and the microbial food web (e.g., Azam et al., 1983; Landry and Kirchman, 2002). The latter is based on bacterial uptake of dissolved organic carbon (DOC), which may be provided by primary production or by external sources, such as river discharge. Lai et al. (2014) conducted two summer cruises in the northern SCS and found evidence to support the malfunctioning microbial-loop hypothesis proposed by Thingstad et al. (1997) that DOC accumulation occurs when bacterial production was low. In contrast to the short DOC turnover time of 37-60 days observed in the inner shelf near the mouth of the Pearl River, it was more than 100 days in the outer shelf and basin region, where the inorganic nutrients were depleted and no correlations were found among bacterial production (BP), DOC 
and primary production (PP) in the shelf-to-basin transition zone (Fig. 4). Inside the mid-shelf (bottom depth $<100 \mathrm{~m}$ ), where inorganic nutrients were abundant, BP, DOC and PP were positively inter-correlated. The availability of limiting minerals could affect the couplings/decouplings between the source (i.e., phytoplankton or riverine supply of DOC) and sink (i.e., bacteria) of organic carbon. This implies that the estuaries and river outflow regions may become more heterotrophic in the future due to increasing anthropogenic nutrient loads, which enhance DOC consumption.

Since the microbial food web composed by protists is likely functioning regardless of the seasons and areas, it is important to biogeochemical cycles and trophic dynamics in pelagic food webs (e.g., Shinada et al., 2001). Tsai et al. (2013) evaluated the impacts of viral lysis and nanoflagellate grazing on bacterial production in the ECS. They demonstrated that viral lysis was similar or more important than protozoan grazing for the dynamics of bacterial community. As significantly biogeochemical and ecological impacts have been emphasized for marine viruses (Fuhrman, 1999), trophic dynamics in microbial food web might be revised by including viruses.

On the other hand, phytoplankton growth and mortality are major drivers of biogeochemical cycles and material flow in pelagic food web. Guo et al. (2014) studied the growth and grazing rates of different picophytoplankton populations in the ECS in an attempt to understand the interactive mechanism of bottom-up and top-down control in regulating picophytoplankton biomass and composition and, consequently, the dynamics of biogeochemical cycling of carbon in the subtropical marginal seas. For the northern SCS, Chen et al. (2013a) compared growth and grazing mortality of phytoplankton community in different depths, seasons and sites using in situ experiments. While microzooplankton grazing was equivalent to more than half of the daily primary production as estimated before (Calbet and Landry, 2004), they were largely variable and decoupled by physical disturbances. The decoupling between growth and mortality may be the result of non-steady-state conditions due to physical forcing and food web complexity, which makes it difficult to predict the grazing mortality at global scales.

Chang et al. (2013) assumed that allometric scaling of phytoplankton cell size of natural assemblage to growth and mortality could be described by the metabolic theory of ecology (MTE). While their experiments in the ECS did not support the MTE, they suggested that the higher grazing impacts of large phytoplankton cells release the grazing mortality of small phytoplankton cells. Metazoans connect grazing and microbial food webs through their feeding on phytoplankton and protozoans (e.g., Kobari et al., 2003), suggesting that metazoan growth is an integration of production at lower trophic levels. Similarly to Chang et al. (2013), Lin et al. (2013) tested the MTE for a copepod community in the ECS. The results from their experiments generally agreed with the MTE because growth rates of the copepod com- munity showed positive correlations with ambient temperature and negative to their body size. These findings suggest trophic interactions among the components are important for biological process of the pelagic ecosystems even in areas, such as the ECS, where the main drivers are external forcing like the Asian monsoon and Kuroshio.

Over the entire ECS, Chen et al. (2014) found that the abundance and community structure of larval fish assemblage changed between the two different monsoon seasons. Under the northeast monsoon in winter, there were two assemblages, the inshore and the offshore assemblages. Under the southwest monsoon in summer, the coverage of the inshore assemblage shrank covering the northern part of the Changjiang River plume, and that of the offshore assemblage expanded, whereas a coastal assemblage occupied the southern part of the Changjiang River plume and the coastal belt further south. They suggested that larval fish assemblage showed higher biodiversity and abundance under the southwest monsoon.

\subsection{Physical forcing and nutrient transport}

The northern ECS is an important spawning and nursery ground for many species of fish and squid. Umezawa et al. (2014) uses $\delta^{15} \mathrm{~N}_{\mathrm{NO}_{3}}, \delta^{18} \mathrm{O}_{\mathrm{NO}_{3}}$ and the $T-S$ relationship to investigate the significance of different nitrate sources in contributing to the nutrient pool and sustaining phytoplankton growth in this region. In winter, Kuroshio Subsurface Water (KSSW) and the Yellow Sea Mixed Water (YSMW) predominantly contributed to the DIN pool in the shelf water, while the warm Kuroshio Surface Water seemed to stimulate phytoplankton growth in the Okinawa Trough with nutrient supplied from the KSSW. In summer, the Changjiang discharge, Yellow Sea Cold Water Mass (YSCWM), and KSSW affected the distribution and abundance of nitrate in the northern ECS. The relative importance of the former two depended on precipitation in the Changjiang drainage basin and the development of the YSCWM in the shelf bottom water, respectively. Aside from oceanic and riverine sources, atmospheric deposition or nitrogen fixation could also have supplied nitrogen to the region as implied by some relatively low $\delta^{15} \mathrm{~N}_{\mathrm{NO}_{3}}$ values observed in the shelf water. They were lower than expected from isotope fractionation during nitrate uptake.

The Kuroshio is the most important nutrient supplier in the western North Pacific Ocean. Based on the absolute geostrophic velocity, which was calculated from the repeated hydrographic data, and nitrate concentration measurements across five sections along the Kuroshio downstream during at least the last decade, Guo et al. (2013) computed the nitrate transport by the Kuroshio Current from the ECS to south of Japan. Their estimated net nitrate transport crossing the PN line within the Okinawa Trough (Fig. 1) is $178.8 \mathrm{kmol} \mathrm{s}^{-1}$, which is larger than that $\left(156.3 \mathrm{kmol} \mathrm{s}^{-1}\right)$ downstream through the Tokara Strait (Fig. 1). This is 
consistent with the notion that, in the region southwest of Kyushu, the Kuroshio branches off to form a KBC that feeds the Tsushima Current and the Yellow Sea Warm Current, which transport nutrients to the ECS, Yellow Sea and the JES. A weak but deep Ryukyu Current contributes to the nitrate transport of the same order as the strong but shallower Kuroshio within the Okinawa Trough along the shelf break of the ECS (Fig. 1). The nitrate flux at every section shows a subsurface maximum core (Fig. 4), which indicates the presence of a stable nutrient stream along the Kuroshio from the East China Sea to the south of Japan. The mean nitrate transport of the Kuroshio along $137^{\circ} \mathrm{E}$, more downstream from the Tokara Strait, is significantly enhanced reaching an estimated value of $\sim 1000 \mathrm{kmol} \mathrm{s}^{-1}$, which is comparable to the Gulf Stream transport (Pelegrí and Csanady, 1991; Pelegrí et al, 1996, 2006; Williams et al., 2011). Guo et al. (2013) concludes that the Kuroshio recirculation has a significant contribution to the downstream increase of nitrate transport as occurred along the Gulf Stream (Williams et al., 2011). This is the first attempt to analyze nutrient and water mass transports in this region.

The rather rich nutrient reserve in the ECS shelf water could serve as a sizable nutrient supply to the oligotrophic northern SCS in winter as suggested by Han et al. (2013). Based on field observations covering both the ECS and the northern SCS, they examined southward long-range transport of nutrients from the ECS to the northeastern SCS carried by the China Coastal Current (CCC) driven by the prevailing northeast monsoon in winter. They estimated a DIN transport of $1430 \pm 1024 \mathrm{~mol} \mathrm{~s}^{-1}$ by combining the field observation of DIN distribution and their estimate of volume transport of the CCC based on both observation and modeling. The redistribution of DIN probably had little effect on the productivity of the ECS, which is not nutrient-limited in winter, but may have a major impact on the northern SCS shelf, where the water temperature was favorable and river-sourced nutrients were limited. Under the assumption that DIN was the limiting nutrient, such southward DIN transport could have sustained a total carbon fixation of $8.84 \pm 6.33 \times 10^{11} \mathrm{gC}$ by phytoplankton, which accounts for $14-22 \%$ of PP in winter in the shelf region to the north of the mouth of the Pearl River. It is noted that the estimated DIN transport, which is at $\sim 1 \%$ level of that carried by the Kuroshio in the ECS, exceeded the total DIN discharge from rivers in winter by a factor of two (Han et al., 2013), indicating that additional supply of DIN could have come from oceanic sources discussed above.

Aside from affecting the basin-wide upwelling (Liu et al., 2013), the intrusion of the Kuroshio into the SCS has more direct consequences as demonstrated by $\mathrm{Du}$ et al. (2013). They used an isopycnal mixing model to quantify the extent of the Kuroshio intrusion and its impact on the nutrient inventory in the northern SCS. Results show that the nutrient inventory in the upper $100 \mathrm{~m}$ of the northern SCS is overall negatively correlated to the Kuroshio water fraction, because the Kuroshio surface water is depleted in nutrients. Conse- quently, the Kuroshio intrusion has complicated and significant influences on nutrient distribution in the SCS and its seasonal variation.

\subsection{Phytoplankton responses to external forcing}

In the study area of this special issue, external forcing, like the Changjiang River discharge, the East Asian monsoon and the Kuroshio, affects greatly and variously the pelagic ecosystems. The maintenance of high primary production in the Ulleung Basin of the JES has been explained by wind-driven coastal upwelling (Hyun et al., 2009; Yoo and Park, 2009), mesoscale eddies, which are often associated with the branch currents of the Kuroshio (Hyun et al., 2009; Kim et al., 2012; Lim et al., 2012), and hydrographic conditions (Kwak et al., 2013a). Kwak et al. (2013b) measured the primary and new productivities in the UB throughout a year. The vertical structure of the water column in the basin is characterized by two distinct features: well-stratified in summer-autumn and wellmixed in winter-spring. Nutrient distributions in euphotic zone show seasonal shift from oligotrophic to eutrophic. Diatoms were in general the most dominant phytoplankton. The annual primary, new and regenerated production in the Ulleung Basin were $273.0 \mathrm{~g} \mathrm{C} \mathrm{m}^{-2} \mathrm{yr}^{-1}, 62.6 \mathrm{~g} \mathrm{~N} \mathrm{~m}^{-2} \mathrm{yr}^{-1}$ and $48.7 \mathrm{~g} \mathrm{~N} \mathrm{~m}^{-2} \mathrm{yr}^{-1}$, respectively. The observed high $f$-ratio (0.59) in the basin indicated the importance of nitrate as the predominant nitrogen source for primary production. Based on high levels of new production, they suggest that a large portion of the total annual primary production might potentially be exported from the diatom-dominated euphotic zone to a deeper zone in the Ulleung Basin. These findings support the conclusion that the Ulleung Basin can be considered as a biological "hot spot" in terms of high phytoplankton productivity and biological pump efficiency. It is noted that the average $\mathrm{C} / \mathrm{N}$ uptake ratio found in this study was $3.4 \pm 0.8$, which is considerably lower than the Redfield ratio.

In contrast to previous studies on the primary production and chlorophyll $a$ distribution based on weekly or monthly composites of satellite ocean color data, Son et al. (2014) reveals highly resolved temporal variation of biochemical properties of the upper layer of the Ulleung Basin in the southwestern JES. Time series measurement of biochemical, optical and physical parameters by an ocean buoy, UBIM (Ulleung Basin Integrated Mooring), during the spring transition highlights an important role of advection of subsurface water mass (i.e., the East Sea Intermediate Water) in triggering the subsurface spring bloom below the surface mixed layer in the Ulleung Basin. Biochemical and collocated physical data suggest that the onset of subsurface spring phytoplankton bloom in the Ulleung Basin is closely associated with low-frequency modulation of the mixed layer depth determined by shoaling and deepening of isothermal depths. Such a time series measurement can give new insight into a 
mechanism that triggers the onset of the spring bloom in the Ulleung Basin.

For the ECS the study of Chen et al. (2013b) also reveals the dramatic changes before and after the spring transition period. They surveyed the ECS in April of 2009 and 2010, and obtained contrasting results of community respiration (CR). In 2009 the $\mathrm{CR}$ ranged from 15 to $307 \mathrm{mg} \mathrm{C} \mathrm{m}^{-3}$ day $^{-1}$ with a mean of $112 \pm 76 \mathrm{mg} \mathrm{C} \mathrm{m}^{-3} \mathrm{day}^{-1}$; in $2010 \mathrm{CR}$ ranged from 43 to $243 \mathrm{mg} \mathrm{C} \mathrm{m}^{-3} \mathrm{~d}^{-1}$ with a mean of $51 \pm 63 \mathrm{mg} \mathrm{C} \mathrm{m}^{-3} \mathrm{day}^{-1}$. They attribute the contrast to the significant difference in phytoplankton biomass as indicated by the ranges and averages of sea surface chlorophyll $a$ concentration: $0.3-7.9(1.8 \pm 2.0) \mathrm{mg} \mathrm{m}^{-3}$ in 2009 and $0.1-$ $5.9(1.3 \pm 1.1) \mathrm{mg} \mathrm{m}^{-3}$ in 2010 . It is likely that the 2009 cruise was during the spring bloom, whereas the 2010 cruise was before the spring bloom or during its early stage. Although the Changjiang river discharge often stimulates algal bloom in the ECS (Gong et al., 2011), the authors note that the higher discharge in 2010 did not induce stronger algal growth. Instead they speculate that the temperature was the main control as indicated by the sea surface temperature (SST) ranges and averages: $15.7-25.3^{\circ} \mathrm{C}\left(19.4 \pm 2.3^{\circ} \mathrm{C}\right)$ in 2009 and $10.6-25.3^{\circ} \mathrm{C}\left(16.9 \pm 4.7^{\circ} \mathrm{C}\right)$ in 2010 .

Sun et al. (2014) describes the distribution of living coccolithophores in the YS and the ECS in summer and winter, and correlation between species and environmental parameters. As observed, the living coccolithophores in the surface layer occurred mainly in the coastal belt and the shelf region south of the mouth of the Changjiang; in winter they were abundant in the continental shelf area along the PN line (Fig. 1). Spatial comparison indicates lower species diversity and less abundance in the YS than those in the ECS in both seasons. They suggest that temperature and the nitrate concentration may be the major environmental factors controlling the distribution and species composition of living coccolithophores. While this is little studied for other seasons, more studies on the seasonal distribution of coccolithophores should be pursued in the future because coccolithophores take on major roles in the marine carbon cycle.

Focusing on the same area plus the BS, $\mathrm{He}$ at al. (2013) investigated long-term changes in the occurrence of phytoplankton blooms using a 14-year time series of satellitederived surface chlorophyll data. They obtained the spatially resolved time series of satellite chlorophyll by merging SeaWiFS and MODIS data and validating it against two in situ data sets from large cruises covering the ECS, YS and BS. By applying an algorithm for the identification of phytoplankton blooms, He et al. (2013) is able to analyze spatial and temporal patterns in bloom distribution. They find a doubling in bloom intensity in the YS and BS over the past 14 years, which they attribute to a doubling in the supply of nitrate and phosphate primarily due to increased nutrient loads from the adjacent rivers. However, in the Changjiang outflow region in the ECS, they find no long-term change in bloom intensity in spite of the reported increase of Changjiang DIN load in the last few decades (Yan et al., 2010). This lack of long-term trend could be due to the same reason mentioned earlier for the lack of long-term trend of $p \mathrm{CO}_{2}$ in the ECS. It is likely that the high variability of water discharge from Changjiang, which controls the productivity as well as $p \mathrm{CO}_{2}$, probably masks the long-term trend.

Although the Changjiang discharge provides ample amount of DIN to the receiving water body, the lack of proportional DIP load in the discharge may induce potential Pstress for phytoplankton. In order to address this issue, Y. F. Tseng et al. (2014) conducted a cruise in the Changjiang plume during summer 2011 to survey distributions of nutrients, chlorophyll $a$ and bulk alkaline phosphatase activity (APA). Their observations reveal a rather complicated situation with P-limitation in the area covered by the Changjiang Diluted Water. In the low salinity end of the plume, where DIN was enriched, high APA was found and its value was inversely related to chlorophyll, indicating its allochthonous origin, probably from limnetic heterotrophic bacteria. The negative correlation implies that phytoplankton growth was not P-limited. This is probably because coastal upwelling and entrainment of subsurface water associated with the moving river plume may bring phosphate-rich Kuroshio Subsurface Water to the euphotic zone to fuel the algal growth. On the other hand, high APA in saline water at the fringe of the plume is a clear sign of P-stress associated with phytoplankton growth (Fig. 4). The strong stratification probably blocked diapycnal phosphate supply at the plume fringe. They conclude that phosphate supply instead of its concentration is probably more important in determining the state of P-limitation, and, therefore, the expression of APA.

It is well known that the variability of surface chlorophyll concentrations in the SCS basin is related to wind forcing, especially during winter monsoon, which leads to a pronounced seasonal cycle in chlorophyll (Liu et al., 2002). Liu et al. (2013) shows that after removing the seasonal cycle, surface chlorophyll responds asymmetrically to wind forcing under El Niño and La Niña conditions. For this purpose, Liu et al. (2013) produced a time series of satellite-derived chlorophyll for a location in the central northern SCS around the SEATS station by merging SeaWiFS and MODIS products in this region and validating it against in situ chlorophyll data from SEATS. Under El Niño conditions, surface chlorophyll is strongly correlated with wind forcing, while under La Niña conditions the correlation is weak (Liu et al., 2013). The weak correlation during La Niña is explained by the deeper thermocline due to weakened SCS throughflow, which diminishes the importance of wind-driven nutrient pumping.

Shang et al. (2014) examines the question of how different chlorophyll products from the MODIS satellite compare to each other and how consistent they are in revealing temporal and spatial patterns in the SCS. This is an important question, especially for optically complex coastal waters in nearshore regions where the accuracy of satellite-derived chlorophyll estimates is likely lower than in the open ocean, because 
chlorophyll is often not the dominant constituent influencing optical properties. Shang et al. (2014) compares products from three different algorithms that are routinely made available to the oceanographic community by NASA and finds that all three algorithms capture essential features such as winter peaks in chlorophyll $a$ and summer bloom associated with the plume of the Pearl River, but differ in the magnitude of these signals; as expected, particularly large deviations occur in nearshore waters. The Shang et al. (2014) analysis also suggests significant uncertainties in the study region when compared to in situ measurements from the SEATS time series station, but found that regional tuning of the algorithms can improve the chlorophyll estimates.

\section{Summary and concluding remarks}

The three major marginal seas in the western North Pacific Ocean, namely, the Japan/East Sea (JES), the East China Sea (ECS) and the South China Sea (SCS), are experiencing multiple stressors induced by anthropogenic as well as natural drivers. However, few long-term trends in biogeochemical conditions or ecosystem functions can be determined mainly due to lack of long-term observations. The only notable longterm biogeochemical trends are the increase of $p \mathrm{CO}_{2}$ in surface waters of the JES and the SCS at significantly faster rates than that at the HOT station, but no clear trend can be discerned in the ECS probably due to the high variability of the Changjiang discharge.

The only long-term trends in ecosystem function are the doubling of the algal bloom intensity in the Bohai Sea and Yellow Sea, attributable to increasing anthropogenic nutrient loads from rivers. At the same time, eutrophicationinduced high primary production in the ECS leads to enhanced acidification in the bottom waters. This notion is corroborated by the observed very high POC fluxes, up to $785 \mathrm{mg} \mathrm{C} \mathrm{m}^{-2}$ day $^{-1}$ in the ECS inner shelf. Even stronger acidification has been observed in the Yellow Sea (YS) in the bottom water in autumn probably due to a longer residence time. Effluents from aquaculture and submarine groundwater discharge off the Hainan Island and atmospheric deposition of airborne DIN in the ECS and the SCS have been observed as additional nutrient sources.

More important than nutrient supplies from land, the Kuroshio carries a DIN load of $179 \mathrm{kmol} \mathrm{N} \mathrm{s}^{-1}$ in the Okinawa Trough, and in parallel, the Ryukyu Current carries a similar DIN load east of the Ryukyu Island Chain. The two currents merge southeast of Honshu with an enhanced recirculation resulting in a very strong DIN transport of $\sim 1000 \mathrm{kmol} \mathrm{N} \mathrm{s}^{-1}$. The Kuroshio Branch Currents along the shelf break serve as major nutrient sources to the ECS shelf as well as the JES. The frontal instability probably induces nutrient pumping via generation of eddies in the JES, which, along with wind driven coastal upwelling, render the Ulleung Basin a biological "hot spot" of high primary and new pro- ductions. By contrast, the intrusion of Kuroshio into the SCS through the Luzon Strait brings nutrient-poor surface water that reduces the nutrient inventory in the northern SCS. On the other hand, the deep inflow into the SCS forms the SCS throughflow that controls the basin wide upwelling and nutrient supply, which in turn control phytoplankton growth. Because the throughflow is modulated by ENSO, a discernible imprint has been detected in the interannual variation of chlorophyll in the SCS. In the northern SCS shelf, additional nutrient supply comes from ECS in the southward flowing China Coast Current driven by the prevailing northeast monsoon in winter. It is highly recommended to investigate how climate change may alter the circulation, especially, the Kuroshio, and, consequently, the nutrient fluxes in the future.

The Changjiang River plume and its interaction with the shelf water and the Kuroshio are closely examined in this special issue. The major features here and in some of the Pearl River outflow region are summarized in Fig. 4. In the turbid estuary and inner shelf, the high concentrations of suspended particulate matter (SPM) support very high nitrification rates, which exceed the values expected from oxygen consumption in half of the samples, suggesting that iron or manganese oxides associated with SPM could have served as oxidants for nitrification.

The potential P-limitation in the river plume due to the imbalance of the $\mathrm{N} / \mathrm{P}$ ratio in the river discharge is probably mitigated by the marine nutrient supply rich in phosphate facilitated by river plume-associated upwelling and entrainment. Severe P-limitation occurs in the outer rim of the river plume, where supply of phosphate from the subsurface water is suppressed. The contrast in nutrient regime in the inner and outer shelves in different seasons also controls the fish larvae assemblage in the ECS. Along the river-shelf-basin continuum, the repletion of inorganic nutrients in the inner shelf sustains a tight coupling between primary production and bacterial production, resulting in fast turnover of dissolved organic carbon (DOC), whereas the nutrient depleted outer shelf and open sea witnesses decoupled PP and BP, leading to slow DOC turnover. These features have been observed mainly in the river-dominated ECS and northern SCS. It is warranted that similar observations should be conducted in other river-dominated continental margins to verify whether the same processes also control the biogeochemical conditions.

It has been increasingly recognized in recent years that time series observations are critical for detecting and attributing environmental changes and ecosystem responses, especially in continental margins (Levin et al., 2015). One good example is the CARIACO time series program in the Cariaco Basin (http://imars.marine.usf.edu/CAR/). Its time series observations reveal decreases in primary production and phytoplankton biomass due to weakened upwelling caused by weakening of the trade wind (Muller-Karger et al., 2013), a shift in phytoplankton community structure from diatomdominated to more abundant pico- and nanoplankton (Taylor 
et al., 2012) and increases in zooplankton biomass following the collapse of the Spanish sardine (Sardinella aurita) fishery (Rueda-Roa, 2012). Such understanding is critical for better assessment of ecosystem health in continental margins.

Therefore, the existing time series programs in the marginal sea, namely, the EAST-I (East Asian Seas Timeseries) program for the JES (e.g., Kang et al., 2003) and the SEATS program for the SCS (Wong et al., 2007) should be sustained and expanded in scope, especially in ecosystem observations. For the ECS, a program similar to the CalCOFI (California Cooperative Oceanic Fisheries Investigations) program (http://www.calcofi.org/) needs to be developed to detect any ecosystem changes that may jeopardize human wellbeing in ecosystem-dependant communities and to better manage the coastal environment and resources.

Acknowledgements. We wish to thank the three reviewers, whose comments helped us improve the paper significantly. We are grateful to the funding agencies (including Ministry of Science and Technology, Taiwan, NSF-C, etc.) that have supported the research projects which have produced the rich outcomes presented in this special issue. We wish to thank most sincerely all of the authors of this special issue, who initially submitted more than 35 contributions. K.-K. Liu acknowledges the support of the Ministry of Science and Technology, Taiwan (grant NSC 102-2611-M-008 -002).

Edited by: C.-K. Kang

\section{References}

NOAA: Sea of Japan large marine ecosystem, available at: http:// www.eoearth.org/view/article/155943, 2013.

NOAA: East China Sea large marine ecosystem available at: http: //www.eoearth.org/view/article/151874, 2011.

Azam, F., Fenchel, T., Field, J. G., Gray, J. S., Meyer-Reil, L. A., and Thingstad, F.: Ecological role of water-column microbes in the sea, Mar. Ecol. Prog. Ser., 10, 257-263, 1983.

Cai, W.-J. and Lohrenz, S. E.: 7.8. The Mississippi River plume and adjacent margin in the Gulf of Mexico, in: Carbon and Nutrient Fluxes in Continental Margins: A Global Synthesis, edited by: Liu, K.-K., Atkinson, L., Quiñones, R., and Talaue-McManus, L., IGBP Book Series, Springer, Berlin, 406-421, 2010.

Cai, W. J., Hu, X. P., Huang, W. J., Murrell, M. C., Lehrter, J. C., Lohrenz, S. E., Chou, W. C., Zhai, W. D., Hollibaugh, J. T., Wang, Y. C., Zhao, P. S., Guo, X. H., Gundersen, K., Dai, M. H., and Gong, G. C.: Acidification of subsurface coastal waters enhanced by eutrophication, Nat. Geosci., 4, 766-770, 2011.

Calbet, A. and Landry, M. R.: Phytoplankton growth, microzooplankton grazing, and carbon cycling in marine systems, Limnol. Oceanogr., 49, 51-57, 2004.

Chang, F. H., Marquis, E. C., Chang, C. W., Gong, G. C., and Hsieh, C. H.: Scaling of growth rate and mortality with size and its consequence on size spectra of natural microphytoplankton assemblages in the East China Sea, Biogeosciences, 10, 5267-5280, doi:10.5194/bg-10-5267-2013, 2013.
Chao, S. Y., Shaw, P. T., and Wu, S. Y.: Deep-Water Ventilation in the South China Sea, Deep-Sea Res. I, 43, 445-466, 1996.

Chen, B., Zheng, L., Huang, B., Song, S., and Liu, H.: Seasonal and spatial comparisons of phytoplankton growth and mortality rates due to microzooplankton grazing in the northern South China Sea, Biogeosciences, 10, 2775-2785, doi:10.5194/bg-10-27752013, 2013a.

Chen, C. C., Gong, G. C., Shiah, F. K., Chou, W. C., and Hung, C. C.: The large variation in organic carbon consumption in spring in the East China Sea, Biogeosciences, 10, 2931-2943, doi:10.5194/bg-10-2931-2013, 2013 b.

Chen, G. X., Gan, J. P., Xie, Q., Chu, X. Q., Wang, D. X., and Hou, Y. J.: Eddy heat and salt transports in the South China Sea and their seasonal modulations, J. Geophys. Res.-Oc., 117, C05021, doi:10.1029/2011jc007724, 2012.

Chen, W. Y., Lee, M. A., Lan, K. W., and Gong, G. C.: Distributions and assemblages of larval fish in the East China Sea during the northeasterly and southwesterly monsoon seasons of 2008, Biogeosciences, 11, 547-561, doi:10.5194/bg-11-547-2014, 2014.

Chou, W. C., Gong, G. C., Cai, W. J., and Tseng, C. M.: Seasonality of $\mathrm{CO}_{2}$ in coastal oceans altered by increasing anthropogenic nutrient delivery from large rivers: evidence from the Changjiang-East China Sea system, Biogeosciences, 10, 38893899, doi:10.5194/bg-10-3889-2013, 2013a.

Chou, W. C., Gong, G. C., Hung, C. C., and Wu, Y. H.: Carbonate mineral saturation states in the East China Sea: present conditions and future scenarios, Biogeosciences, 10, 6453-6467, doi:10.5194/bg-10-6453-2013, 2013b.

Dai, M., Guo, X., Zhai, W., Yuan, L., Wang, B., Wang, L., Cai, P., Tang, T., and Cai, W.-J.: Oxygen depletion in the upper reach of the Pearl River estuary during a winter drought, Mar. Chem., 102, 159-169, 2006.

Du, C., Liu, Z., Dai, M., Kao, S. J., Cao, Z., Zhang, Y., Huang, T., Wang, L., and Li, Y.: Impact of the Kuroshio intrusion on the nutrient inventory in the upper northern South China Sea: insights from an isopycnal mixing model, Biogeosciences, 10, 6419-6432, doi:10.5194/bg-10-6419-2013, 2013.

Fennel, K., Hu, J. T., Laurent, A., Marta-Almeida, M., and Hetland, R.: Sensitivity of hypoxia predictions for the northern Gulf of Mexico to sediment oxygen consumption and model nesting, J. Geophys. Res.-Oc., 118, 990-1002, 2013.

Fuhrman, J. A.: Marine viruses and their biogeochemical and ecological effects, Nature, 399, 541-548, 1999.

Gong, G. C., Liu, K. K., Chiang, K. P., Hsiung, T. M., Chang, J., Chen, C. C., Hung, C. C., Chou, W. C., Chung, C. C., Chen, H. Y., Shiah, F. K., Tsai, A. Y., Hsieh, C. H., Shiao, J. C., Tseng, C. M., Hsu, S. C., Lee, H. J., Lee, M. A., Lin, II, and Tsai, F. J.: Yangtze River floods enhance coastal ocean phytoplankton biomass and potential fish production, Geophys. Res. Lett., 38, L13603, doi:10.1029/2011g1047519, 2011.

Gordon, A. L., Huber, B. A., Metzger, E. J., Susanto, R. D., Hurlburt, H. E., and Adi, T. R.: South China Sea throughflow impact on the Indonesian throughflow, Geophys. Res. Lett., 39, L11602, doi:10.1029/2012g1052021, 2012.

Guo, C., Liu, H., Zheng, L., Song, S., Chen, B., and Huang, B.: Seasonal and spatial patterns of picophytoplankton growth, grazing and distribution in the East China Sea, Biogeosciences, 11, 1847-1862, doi:10.5194/bg-11-1847-2014, 2014. 
Guo, X. Y., Zhu, X. H., Long, Y., and Huang, D. J.: Spatial variations in the Kuroshio nutrient transport from the East China Sea to south of Japan, Biogeosciences, 10, 6403-6417, doi:10.5194/bg-10-6403-2013, 2013.

Han, A. Q., Dai, M. H., Gan, J. P., Kao, S. J., Zhao, X. Z., Jan, S., Li, Q., Lin, H., Chen, C. T. A., Wang, L., Hu, J. Y., Wang, L. F., and Gong, F.: Inter-shelf nutrient transport from the East China Sea as a major nutrient source supporting winter primary production on the northeast South China Sea shelf, Biogeosciences, 10, 81598170, doi:10.5194/bg-10-8159-2013, 2013.

He, X., Bai, Y., Pan, D., Chen, C. T. A., Cheng, Q., Wang, D., and Gong, F.: Satellite views of the seasonal and interannual variability of phytoplankton blooms in the eastern China seas over the past $14 \mathrm{yr}$ (1998-2011), Biogeosciences, 10, 4721-4739, doi:10.5194/bg-10-4721-2013, 2013.

Hsiao, S. S. Y., Hsu, T. C., Liu, J. w., Xie, X., Zhang, Y., Lin, J., Wang, H., Yang, J. Y. T., Hsu, S. C., Dai, M., and Kao, S. J.: Nitrification and its oxygen consumption along the turbid Chang Jiang River plume, Biogeosciences, 11, 2083-2098, doi:10.5194/bg-11-2083-2014, 2014.

Hsu, S.-C., Liu, S. C., Arimoto, R., Liu, T.-H., Huang, Y.-T., Tsai, F., Lin, F.-J., and Kao, S.-J.: Dust deposition to the East China Sea and its biogeochemical implications, J. Geophys. Res.-Atmos., 114, D15304, doi:10.1029/2008jd011223, 2009.

Hung, C. C., Tseng, C. W., Gong, G. C., Chen, K. S., Chen, M. H., and Hsu, S. C.: Fluxes of particulate organic carbon in the East China Sea in summer, Biogeosciences, 10, 6469-6484, doi:10.5194/bg-10-6469-2013, 2013.

Hyun, J. H., Kim, D., Shin, C. W., Noh, J. H., Yang, E. J., Mok, J. S., Kim, S. H., Kim, H. C., and Yoo, S.: Enhanced phytoplankton and bacterioplankton production coupled to coastal upwelling and an anticyclonic eddy in the Ulleung basin, East Sea, Aq. Microb. Ecol., 54, 45-54, doi:10.3354/ame01280, 2009.

Ichikawa, H. and Beardsley, R. C.: Temporal and spatial variability of volume transport of the Kuroshio in The East China Sea, Deep-Sea Res. Pt. I, 40, 583-605, 1993.

Ichikawa, H. and Beardsley, R. C.: The current system in the Yellow and East China Seas, J. Oceanogr., 58, 77-92, 2002.

Jennerjahn, T. C.: Biogeochemical response of tropical coastal systems to present and past environmental change, Earth-Sci. Rev., 114, 19-41, 2012.

Kang, D.-J., Lee, K.-E., and Kim, K.-R.: Recent developments in chemical oceanography of the East (Japan) Sea with an emphasis on CREAMS findings: A review, Geosci. J., 7, 179-197, 2003.

Kang, D.-J., Kim, J.-Y., Lee, T., and Kim, K.-R.: 7.6. The East Sea (Sea of Japan), in: Carbon and Nutrient Fluxes in Continental Margins: A Global Synthesis, edited by: Liu, K.-K., Atkinson, L., Quiñones, R., and Talaue-McManus, L., IGBP Book Series, Springer, Berlin, 383-394, 2010.

Kim, D., Yang, E. J., Kim, K. H., Shin, C. W., Park, J., Yoo, S., and Hyun, J. H.: Impact of an anticyclonic eddy on the summer nutrient and chlorophyll a distributions in the Ulleung Basin, East Sea (Japan Sea), Ices J. Mari. Sci., 69, 23-29, 2012.

Kim, J. Y., Kang, D. J., Lee, T., and Kim, K. R.: Long-term trend of $\mathrm{CO}_{2}$ and ocean acidification in the surface water of the Ulleung Basin, the East/Japan Sea inferred from the underway observational data, Biogeosciences, 11, 2443-2454, doi:10.5194/bg-112443-2014, 2014.
Kim, T. W., Lee, K., Najjar, R. G., Jeong, H. D., and Jeong, H. J.: Increasing $\mathrm{N}$ abundance in the northwestern Pacific Ocean due to atmospheric nitrogen deposition, Science, 334, 505-509, 2011.

Kobari, T., Shinada, A., and Tsuda, A.: Functional roles of interzonal migrating mesozooplankton in the western subarctic Pacific, Prog. Oceanogr., 57, 279-298, 2003.

Kwak, J. H., Hwang, J., Choy, E. J., Park, H. J., Kang, D. J., Lee, T., Chang, K. I., Kim, K. R., and Kang, C. K.: High primary productivity and f-ratio in summer in the Ulleung basin of the East/Japan Sea, Deep-Sea Res. Pt. I, 79, 74-85, 2013 a.

Kwak, J. H., Lee, S. H., Park, H. J., Choy, E. J., Jeong, H. D., Kim, K. R., and Kang, C. K.: Monthly measured primary and new productivities in the Ulleung Basin as a biological "hot spot" in the East/Japan Sea, Biogeosciences, 10, 4405-4417, 2013b, http://www.biogeosciences.net/10/4405/2013/.

Lai, C. C., Fu, Y. W., Liu, H. B., Kuo, H. Y., Wang, K. W., Lin, C. H., Tai, J. H., Wong, G. T. F., Lee, K. Y., Chen, T. Y., Yamamoto, Y., Chow, M. F., Kobayashi, Y., Ko, C. Y., and Shiah, F. K.: Distinct bacterial-production-DOC-primary-production relationships and implications for biogenic $\mathrm{C}$ cycling in the South China Sea shelf, Biogeosciences, 11, 147-156, doi:10.5194/bg11-147-2014, 2014.

Landry, M. R. and Kirchman, D. L.: Microbial community structure and variability in the tropical Pacific, Deep-Sea Res. II, 49, 2669 2693, 2002.

Lee, H. J. and Chao, S. Y.: A climatological description of circulation in and around the East China Sea, Deep-Sea Res. Pt. II, 50, 1065-1084, 2003.

Lee, H. J., Chao, S. Y., and Liu, K. K.: Effects of reduced Yangtze River discharge on the circulation of surrounding seas, Terrest. Atmos. Oc. Sci., 15, 111-132, 2004.

Levin, L. A., Liu, K.-K., Emeis, K.-C., Breitburg, D. L., Cloern, J., Deutsch, C., Giani, M., Goffart, A., Hofmann, E. E., Lachkar, Z., Limburg, K., Liu, S.-M., Montes, E., Naqvi, W., Ragueneau, O., Rabouille, C., Sarkar, S. K., Swaney, D. P., Wassman, P., and Wishner, K. F.: Comparative biogeochemistry-ecosystem-human interactions on dynamic continental margins, J. Mar. Syst., 141, 3-17, doi:10.1016/j.jmarsys.2014.04.016, 2015.

Li, R. H., Liu, S. M., Li, Y. W., Zhang, G. L., Ren, J. L., and Zhang, J.: Nutrient dynamics in tropical rivers, lagoons, and coastal ecosystems of eastern Hainan Island, South China Sea, Biogeosciences, 11, 481-506, doi:10.5194/bg-11-481-2014, 2014.

Lie, H. J., Cho, C. H., Lee, J. H., Lee, S., Tang, Y. X., and Zou, E. M.: Does the Yellow Sea Warm Current really exist as a persistent mean flow?, J. Geophys. Res.-Oc., 106, 22199-22210, 2001.

Lim, J.-H., Son, S., Park, J.-W., Kwak, J. H., Kang, C.-K., Son, Y.B., Kwon, J. N., and Lee, S. H.: Enhanced biological activity by an anticyclonic warm eddy during early spring in the East Sea (Japan Sea) detected by the geostationary ocean color satellite, Ocean Sci. J., 47, 377-385, 2012.

Lin, I. I., Chen, J.-P., Wong, G. T. F., Huang, C.-W., and Lien, C.-C.: Aerosol input to the South China Sea: Results from the MODerate resolution Imaging Spectro-radiometer, the quick scatterometer, and the measurements of pollution in the troposphere sensor, Deep-Sea Res. II, 54, 1589-1601, 2007.

Lin, K. Y., Sastri, A. R., Gong, G. C., and Hsieh, C. H.: Copepod community growth rates in relation to body size, temperature, and food availability in the East China Sea: a test of 
metabolic theory of ecology, Biogeosciences, 10, 1877-1892, doi:10.5194/bg-10-1877-2013, 2013.

Liu, K.-K., Gong, G.-C., Lin, S., Yang, C.-Y., Wei, C.-L., Pai, S.-C., and $\mathrm{Wu}, \mathrm{C} . \mathrm{K}$.: The year-round upwelling at the shelf break near the northern tip of Taiwan as evidenced by chemical hydrography., Terrest. Atmos. Oc. Sci., 3, 243-275, 1992a.

Liu, K.-K., Gong, G.-C., Shyu, C.-Z., Pai, S.-C., Wei, C.-L., and Chao, S.-Y.: Response of Kuroshio upwelling to the onset of northeast monsoon in the sea north of Taiwan: observations and a numerical simulation, J. Geophys. Res.-Oc., 97, 12511-12526, $1992 b$.

Liu, K.-K., Chao, S.-Y., Shaw, P.-T., Gong, G.-C., Chen, C.-C., and Tang, T.-Y.: Monsoon-forced chlorophyll distribution and primary production in the South China Sea: observations and a numerical study, Deep-Sea Res. II, 49, 1387-1412, 2002.

Liu, K.-K., Gong, G.-C., Wu, C.-R., and Lee, H.-J.: 3.2. The Kuroshio and the East China Sea, in: Carbon and Nutrient Fluxes in Continental Margins: A Global Synthesis, edited by: Liu, K.K., Atkinson, L., Quiñones, R., and Talaue-McManus, L., IGBP Book Series, Springer, Berlin, 124-146, 2010a.

Liu, K.-K., Tseng, C.-M., Wu, C.-R., and Lin, I.-I.: 8.6. The South China Sea, in: Carbon and Nutrient Fluxes in Continental Margins: A Global Synthesis, edited by: Liu, K.-K., Atkinson, L., Quiñones, R., and Talaue-McManus, L., IGBP Book Series, Springer, Berlin, 464-482, 2010 b.

Liu, K.-K., Dai, M., Kim, K.-R., and Gong, G.-C.: Preface: Biogeochemistry and ecosystems in the western north Pacific continental margins under climate change and anthropogenic forcing, Biogeosci., 11, 4967-4969, doi:10.5194/bg-11-4967-2014, 2014.

Liu, K.-K., Yan, W., Lee, H.-J., Chao, S.-Y., Gong, G.-C., and Yeh, T.-Y.: Impacts of increasing dissolved inorganic nitrogen discharge from Changjiang on primary production and seafloor oxygen demand in the East China Sea from 1970 to 2002, J. Mar. Systems, 141, 200-217, doi:10.1016/j.jmarsys.2014.07.022, 2015.

Liu, K. K., Wang, L. W., Dai, M., Tseng, C. M., Yang, Y., Sui, C. H., Oey, L., Tseng, K. Y., and Huang, S. M.: Inter-annual variation of chlorophyll in the northern South China Sea observed at the SEATS Station and its asymmetric responses to climate oscillation, Biogeosciences, 10, 7449-7462, doi:10.5194/bg-107449-2013, 2013.

Muller-Karger, F. E., Lorenzoni, L., Montes, E., Thunell, R. C., Taylor, G. T., Scranton, M. I., Benitez-Nelson, C. R., Astor, Y., Varela, R., Troccoli, L., and Fanning, K. A.: The CARIACO Ocean Time-Series: 18 years of international collaboration in ocean biogeochemistry and ecological research, Oc. Carb. Biogeochem. Newsletter, fall edition, 7-12, 2013.

Pelegri, J. L. and Csanady, G. T.: Nutrient transport and mixing in the Gulf Stream, J. Geophys. Res.-Oc., 96, 2577-2583, 1991.

Pelegrí, J. L., Csanady, G. T., and Martins, A.: The North Atlantic nutrient stream, J. Oceanogr., 52, 275-299, 1996.

Pelegri, J. L., Marrero-Diaz, A., and Ratsimandresy, A. W.: Nutrient irrigation of the North Atlantic, Prog. Oceanogr., 70, 366-406, 2006.

Qiu, B.: The Kuroshio Extension system: Its large-scale variability and role in the midlatitude ocean-atmosphere interaction, J. Oceanogr., 58, 57-75, 2002.
Rhein, M., Rintoul, S. R., Aoki, S., Campos, E., D. Chambers, Feely, R. A., Gulev, S., Johnson, G. C., Josey, S. A., Kostianoy, A., Mauritzen, C., Roemmich, D., Talley, L. D., and Wang, F.: Observations: Ocean, in: Climate Change 2013: The Physical Science Basis. Contribution of Working Group I to the Fifth Assessment Report of the Intergovernmental Panel on Climate Change, edited by: Stocker, T. F., Qin, D., Plattner, G.-K., Tignor, M., Allen, S. K., Boschung, J., Nauels, A., Xia, Y., Bex, V., and Midgley, P. M., Cambridge University Press, Cambridge, United Kingdom and New York, NY, USA, 2013.

Rueda-Roa, D. T.: On the spatial and temporal variability of upwelling in the southern Caribbean Sea and its influence on the ecology of phytoplankton and of the Spanish sardine (Sardinella aurita), PhD, University of South Florida, 2012.

Senjyu, T.: The Japan Sea Intermediate Water; its characteristics and circulation, J. Oceanogr., 55, 111-122, 1999.

Shang, S. L., Dong, Q., Hu, C. M., Lin, G., Li, Y. H., and Shang, S. P.: On the consistency of MODIS chlorophyll $a$ products in the northern South China Sea, Biogeosciences, 11, 269-280, doi:10.5194/bg-11-269-2014, 2014.

Shaw, P. T. and Chao, S. Y.: Surface Circulation in the South China Sea, Deep Sea Res. Pt. 1, 41, 1663-1683, 1994.

Shinada, A., Ikeda, T., Ban, S., and Tsuda, A.: Seasonal dynamics of plankton food chain in the Oyashio region, western Subarctic Pacific, J. Plank. Res., 23, 1237-1247, 2001.

Son, Y. T., Chang, K. I., Yoon, S. T., Rho, T., Kwak, J. H., Kang, C. K., and Kim, K. R.: A newly observed physical cause of the onset of the subsurface spring phytoplankton bloom in the southwestern East Sea/Sea of Japan, Biogeosciences, 11, 1319-1329, doi:10.5194/bg-11-1319-2014, 2014.

Sun, J., Gu, X. Y., Feng, Y. Y., Jin, S. F., Jiang, W. S., Jin, H. Y., and Chen, J. F.: Summer and winter living coccolithophores in the Yellow Sea and the East China Sea, Biogeosciences, 11, 779806, doi:10.5194/bg-11-779-2014, 2014.

NOAA: South China Sea large marine ecosystem, available at: http: //www.eoearth.org/view/article/156129, 2011.

Taylor, G. T., Muller-Karger, F. E., Thunell, R. C., Scranton, M. I., Astor, Y., Varela, R., Ghinaglia, L. T., Lorenzoni, L., Fanning, K. A., and Hameed, S.: Ecosystem responses in the southern Caribbean Sea to global climate change, Proc. Natl. Acad. Sci., 109, 19315-19320, 2012.

Thingstad, T. F., Hagstrom, A., and Rassoulzadegan, F.: Accumulation of degradable DOC in surface waters: Is it caused by a malfunctioning microbial loop?, Limnol. Oceanogr., 42, 398-404, 1997.

Thomas, H., Bozec, Y., Elkalay, K., and de Baar, H. J. W.: Enhanced open ocean storage of $\mathrm{CO} 2$ from shelf sea pumping, Science, 304, 1005-1008, 2004.

Tsai, A. Y., Gong, G. C., and Hung, J.: Seasonal variations of virusand nanoflagellate-mediated mortality of heterotrophic bacteria in the coastal ecosystem of subtropical western Pacific, Biogeosciences, 10, 3055-3065, doi:10.5194/bg-10-3055-2013, 2013.

Tseng, C.-M., Shen, P.-Y., and Liu, K.-K.: Synthesis of observed air-sea $\mathrm{CO}_{2}$ exchange fluxes in the river-dominated East China Sea and improved estimates of annual and seasonal net mean fluxes, Biogeosciences, 11, 1-16, doi:10.5194/bg-11-1-2014, 2014.

Tseng, C. M., Wong, G. T. F., Chou, W. C., Lee, B. S., Sheu, D. D., and Liu, K. K.: Temporal variations in the carbonate system 
in the upper layer at the SEATS station, Deep-Sea Res. II, 54, 1448-1468, 2007.

Tseng, C. M., Liu, K. K., Gong, G. C., Shen, P. Y., and Cai, W. J.: $\mathrm{CO}_{2}$ uptake in the East China Sea relying on Changjiang runoff is prone to change, Geophys. Res. Lett., 38, L24609, doi:10.1029/2011g1049774, 2011.

Tseng, Y. F., Lin, J., Dai, M., and Kao, S. J.: Joint effect of freshwater plume and coastal upwelling on phytoplankton growth off the Changjiang River, Biogeosciences, 11, 409-423, doi:10.5194/bg-11-409-2014, 2014.

Tsunogai, S., Watanabe, S., and Sato, T.: Is there a "continental shelf pump" for the absorption of atmospheric $\mathrm{CO}_{2}$ ?, Tellus, 51B, 701-712, 1999.

Umezawa, Y., Yamaguchi, A., Ishizaka, J., Hasegawa, T., Yoshimizu, C., Tayasu, I., Yoshimura, H., Morii, Y., Aoshima, T., and Yamawaki, N.: Seasonal shifts in the contributions of the Changjiang River and the Kuroshio Current to nitrate dynamics in the continental shelf of the northern East China Sea based on a nitrate dual isotopic composition approach, Biogeosciences, 11, 1297-1317, doi:10.5194/bg-11-1297-2014, 2014.

Wang, S. H., Hsu, N. C., Tsay, S. C., Lin, N. H., Sayer, A. M., Huang, S. J., and Lau, W. K. M.: Can Asian dust trigger phytoplankton blooms in the oligotrophic northern South China Sea?, Geophys. Res. Lett., 39, L05811, doi:10.1029/2011g1050415, 2012.

Williams, R. G., McDonagh, E., Roussenov, V. M., Torres-Valdes, S., King, B., Sanders, R., and Hansell, D. A.: Nutrient streams in the North Atlantic: Advective pathways of inorganic and dissolved organic nutrients, Global Biogeochem. Cy., 25, GB4008, doi:10.1029/2010gb003853, 2011.

Wong, G. T. F., Ku, T.-L., Mulholland, M., Tseng, C.-M., and Wang, D.-P.: The SouthEast Asian Time-series Study (SEATS) and the biogeochemistry of the South China Sea: an overview, Deep-Sea Res. II, 54, 1434-1447, 2007.
Yan, W. J., Mayorga, E., Li, X. Y., Seitzinger, S. P., and Bouwman, A. F.: Increasing anthropogenic nitrogen inputs and riverine DIN exports from the Changjiang River basin under changing human pressures, Global Biogeochem. Cy., 24, Gb0a06, doi:10.1029/2009gb003575, 2010.

Yang, J. Y. T., Hsu, S. C., Dai, M. H., Hsiao, S. S. Y., and Kao, S. J.: Isotopic composition of water-soluble nitrate in bulk atmospheric deposition at Dongsha Island: sources and implications of external N supply to the northern South China Sea, Biogeosciences, 11, 1833-1846, doi:10.5194/bg-11-1833-2014, 2014.

Yoo, S. and Park, J.: Why is the southwest the most productive region of the East Sea/Sea of Japan?, J. Mar. Syst., 78, 301-315, 2009.

Zhai, W. D., Dai, M. H., Chen, B. S., Guo, X. H., Li, Q., Shang, S. L., Zhang, C. Y., Cai, W. J., and Wang, D. X.: Seasonal variations of sea-air $\mathrm{CO}_{2}$ fluxes in the largest tropical marginal sea (South China Sea) based on multiple-year underway measurements, Biogeosciences, 10, 7775-7791, doi:10.5194/bg-107775-2013, 2013.

Zhai, W. D., Zheng, N., Huo, C., Xu, Y., Zhao, H. D., Li, Y. W., Zang, K. P., Wang, J. Y., and Xu, X. M.: Subsurface $\mathrm{pH}$ and carbonate saturation state of aragonite on the Chinese side of the North Yellow Sea: seasonal variations and controls, Biogeosciences, 11, 1103-1123, doi:10.5194/bg-11-1103-2014, 2014.

Zhu, Z. Y., Zhang, J., Wu, Y., Zhang, Y. Y., Lin, J., and Liu, S. M.: Hypoxia off the Changjiang (Yangtze River) Estuary: Oxygen depletion and organic matter decomposition, Mar. Chem., 125, 108-116, 2011. 